\title{
浸炭材の疲労強度に及ぼすショットピーニング条件の影響
}

加藤万規男 $* 1$, 松村康志 $* 2$, 石倉亮平 $* 2$, 小林祐次 $* 3$, 宇治橋諭 $* 3$

\section{Influence of Shot Peening Condition on the Fatigue Strength of the Carburizing Steel}

\author{
Makio Kato, Yasushi Matsumura, Ryohei Ishikura, Yuji Kobayashi, and Satoru Ujihashi
}

\section{Synopsis}

The present work investigated that the influence of shot peening condition on the fatigue strength when the compressive residual stress of $2000 \mathrm{MPa}$ or more was given to the carburizing steel. The fatigue strength is improved more than the conventional shot peened specimens.

Considering the fatigue crack propagation process, the fatigue crack propagation tends to be obstructed by giving the compressive residual stress to a large, deeper area, and to improve the fatigue strength.

The fatigue strength changes by the quality situation of the surface. In the case of giving a high compressive residual stress to the surface, it is necessary to consider not only the fatigue crack progagation but also the cracking as an influence on the fatigue strength.

\section{1. 緒言}

歯車やシャフトなどの各種浸炭部品の高強度化のニー ズが高まり, 疲労強度向上を目的としてショットピーニ ング処理の適用が拡大してきた。ショットピーニング処 理適用による疲労強度の大幅な向上は, 表面近傍の不均 一塑性ひずみの発生による圧縮残留応力の付与と硬さの 向上で説明されるが, ショット粒の硬度, 粒径, 投射速 度，投射時間などのショットピーニング処理条件によっ て, 付与される残留応力のレベルが異なり, また, ショッ トピーニング処理後の硬さや表面性状もさまざまに変化 すると考えられる

従来より, 高強度化ニーズに対応するため, 浸炭部品 の高硬度化が図られ，ショットピーニング処理に関して は，より高硬度の投射材が求められるようになってきて いる。 これらの高硬度の投射材を用いたショットピーニ ング処理を適用した場合には, 付与される圧縮残留応力 も大きくなるが, 一方では, 表面性状が悪化することが 知られており ${ }^{1)}$, 疲労強度の向上には, ショットピーニ
ング処理条件を最適化する必要があると考えられる.

これらの状況から, 過去にもショットピーニング処理 条件が疲労強度に及ぼす影響を調査した数多くの報告が 見られる. 圧縮残留応力の最大化を志向し, $2000 \mathrm{MPa}$ 程 度の圧縮残留応力を付与した報告として, 衛藤ら 2)は, ショットピーニング処理時に予応力を与え, また, 松井 ら 3) は, 高周波焼入を適用し結晶粒微細化を行っている が，実用化に向けた処理条件の適正化などの課題が多い と考えられる.

そこで本研究では, 硬さ $900 \mathrm{HV}$ から $950 \mathrm{HV}$ の投射 材を用いた高硬度ショットピーニング処理を行い, 2000 $\mathrm{MPa}$ 以上の圧縮残留応力を付与した場合の疲労強度に及 ぼすショットピーニング処理条件の影響について報告す る.

\section{2. 実験方法}

\section{1 供試材}

今回，実験には，一般的に用いられているJIS 肌焼鋼 
を用いた。供試材の成分を Table 1 に示す.

供試材としては, Table 1 に示した成分を 70 ton アーク 炉および炉外精錬設備で溶製した材料を用いた。溶製材 を熱間圧延によって直径 $\phi 85 \mathrm{~mm}$ の棒鋼に成形した後, 熱間鍛造によって直径 $\phi 26 \mathrm{~mm}$ の棒鋼を成形し，その後 $1198 \mathrm{~K}$ の焼きならし処理を施し, これを切削加工するこ とによって $\phi 19 \times 100 \mathrm{~mm}$ の円柱状試験片に仕上げた.

\section{2 浸炭処理およびショットピーニング 処理}

Fig.1に浸炭の処理条件を示す。浸炭処理は, $1203 \mathrm{~K}$ での浸炭処理を行い, 試験片のノッチ底表面の炭素濃度 を約 $0.75 \mathrm{wt} \%$ に調整した。なお，本研究では，試験片が 高硬度ショットピーニング (SP) 処理による面粗度の劣化 を抑制するため, 浸炭異常層を発生させない真空雲囲気 下で処理を行った。 また, 浸炭部品の高硬度化を図るため, 低温焼戻し処理を行った。

今回適用した SP 処理の条件を Table 2 に示す。本研究 では, $2000 \mathrm{MPa}$ 以上の圧縮残留応力を付与するため, 硬 さ $900 \mathrm{HV}$ から $950 \mathrm{HV}$ の投射材を適用した。 また，疲労 強度に及ぼす圧縮残留応力ピーク位置の影響を評価する ため, 平均粒径 $\phi 0.05 \mathrm{~mm}$ から $\phi 0.6 \mathrm{~mm}$ の投射材を用 いて，これをエア式の投射機を用いて投射した。さらに， 比較対象として, 従来から歯車, シャフトなどの浸炭部 品に適用されている条件として, 硬さ $700 \mathrm{HV}$, 平均粒径 $\phi 0.6 \mathrm{~mm}$ の投射材を用いた，いわゆるへビーピーニング (HP) も合わせて評価した. SP 処理のイメージを Fig.2に 示す.

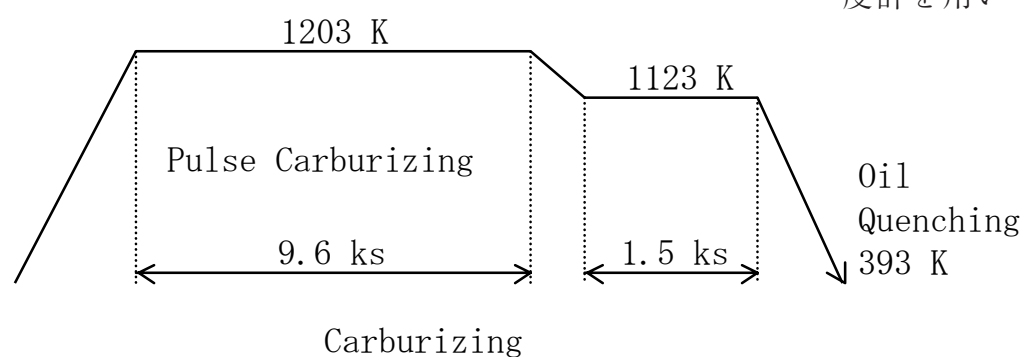

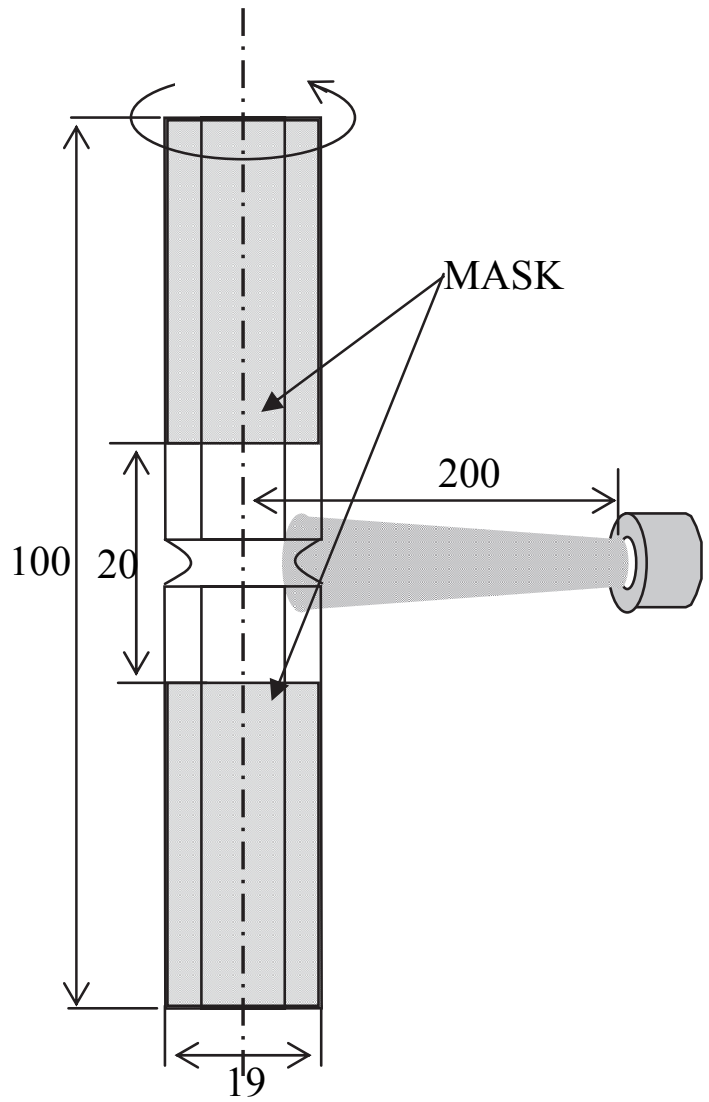

Fig.2. Treating method of SP.

\section{3 硬さおよび残留応力分布の測定}

浸炭処理後および SP 後の硬さは， $\phi 19 \mathrm{~mm} \times 100 \mathrm{~mm}$ の試験片のノッチ底の縦断面を, マイクロビッカース硬 度計を用いて測定した。また，測定荷重は $2.94 \mathrm{~N}$ とし

Fig.1. Heat treatment process of vacuum carburizing.

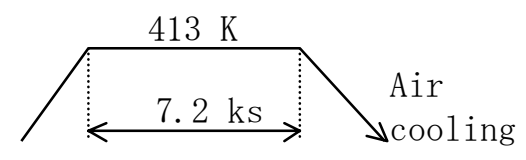

Tempering

Table 1. Chemical compositions of steel [wt\%].

\begin{tabular}{c|c|c|c|c|c|c|c|c|c}
\hline Steel & $\mathrm{C}$ & $\mathrm{Si}$ & $\mathrm{Mn}$ & $\mathrm{P}$ & $\mathrm{S}$ & $\mathrm{Cu}$ & $\mathrm{Ni}$ & $\mathrm{Cr}$ & $\mathrm{Mo}$ \\
\hline Tested steel & 0.20 & 0.20 & 0.75 & 0.013 & 0.013 & 0.15 & 0.10 & 1.10 & 0.15 \\
\hline
\end{tabular}

Table 2. Shot peening condition for test specimen.

\begin{tabular}{c|c|c|c|c}
\hline & No.1 & No.2 & No.3 & No.4 \\
\hline Shot dia. & $\phi 0.05 \mathrm{~mm}$ & $\phi 0.30 \mathrm{~mm}$ & $\phi 0.60 \mathrm{~mm}$ & $\phi 0.60 \mathrm{~mm}$ \\
\hline Shot hardness & Approx.HV 900 & Approx.HV 950 & Approx.HV 950 & Approx.HV 700 \\
\hline Arc height & $0.26 \mathrm{mmN}$ & $0.37 \mathrm{mmA}$ & $0.78 \mathrm{mmA}$ & $0.70 \mathrm{mmA}$ \\
\hline Coverage & $300 \%$ & $300 \%$ & $300 \%$ & $300 \%$ \\
\hline
\end{tabular}


た. 最表層部を基準として, 半径方向への距離（深さ） $0.02 \mathrm{~mm}$ の位置から $2.0 \mathrm{~mm}$ の位置までの測定結果を硬さ プロファイルとして整理し, 浸炭処理および SP 処理によ る硬化層深さも数值化した。 以下, 特に断わらなければ, 「表層硬さ」は $0.02 \mathrm{~mm}$ 位置の硬さを意味する。

残留応力 $\left(\sigma_{\mathrm{R}}\right)$ の測定は X 線回折法 $\left(\sin ^{2} \phi\right.$ 法) によ り行った。 $\sigma_{\mathrm{R}}$ の測定位置は試験片のノッチ底とし, 電 解研磨によって表面層の除去を行いながら測定を繰り返 すことで，試験片の半径方向（深さ方向）への $\sigma_{\mathrm{R}}$ 分布 も調査した。 なお, 以下 $\sigma_{\mathrm{R}}$ としては, 円周方向の残留 応力值を意味する。

\section{4 疲労試験}

疲労強度は, 応力比 0.1 の曲げ疲労試験における $10^{5}$ 回 付近の時間強度を評価した。試験片は歯車の歯底部を想 定し, 応力集中係数 2 の切欠形状とした. 試験片の形状 をFig.3に, 疲労試験の条件を Table 3 に示す。

\section{3. 実験結果および考察}

\section{1 浸炭材の特性}

Fig.4に浸炭処理後の試験片表層部の光学顕微鏡組織写
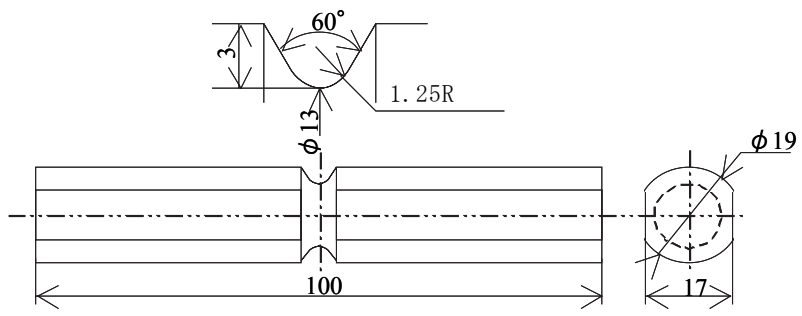

Fig.3. Shape of bending fatigue test specimen.

Table 3. Bending fatigue test condition.

\begin{tabular}{c|c}
\hline Testing machine & Oil pressure servo exam. machine \\
\hline Control method & Load control \\
\hline Atmosphere & Room temperature \\
\hline Determination of life & Rupture life \\
\hline
\end{tabular}

Table 4. Carburizing properties.

\begin{tabular}{|c|c|c|c|c|c|c|}
\hline \multicolumn{2}{|c|}{ SP condition } & \multirow{2}{*}{$\begin{array}{c}\begin{array}{c}\text { As } \\
\text { carburized }\end{array} \\
811\end{array}$} & \multirow{2}{*}{$\begin{array}{l}\text { No.1 } \\
879\end{array}$} & \multirow{2}{*}{$\begin{array}{c}\text { No.2 } \\
916\end{array}$} & \multirow{2}{*}{$\begin{array}{c}\text { No.3 } \\
916\end{array}$} & \multirow{2}{*}{$\begin{array}{l}\text { No.4 } \\
934\end{array}$} \\
\hline $\begin{array}{l}\text { Hardness } \\
\text { (at surface) }\end{array}$ & $\mathrm{Hv}$ & & & & & \\
\hline $\begin{array}{c}\text { Effective } \\
\text { case depth }\end{array}$ & $\mathrm{mm}$ & 0.74 & 0.74 & 0.67 & 0.64 & 0.69 \\
\hline $\begin{array}{l}\text { Retained } \\
\text { austenite }\end{array}$ & vol\% & 21.4 & 7.9 & 16.9 & 17.2 & 18.3 \\
\hline $\begin{array}{l}\text { Max. residual } \\
\text { stress }\end{array}$ & $\mathrm{MPa}$ & -199 & -2065 & -2127 & -2030 & -1490 \\
\hline $\begin{array}{l}\text { Depth of Max. } \\
\text { Residual stress }\end{array}$ & $\mu \mathrm{m}$ & 0 & 5 & 30 & 60 & 40 \\
\hline
\end{tabular}


表面粗さ (Ra) は, 投射材の平均粒径が大きくなるほど悪 くなることが確認でき，平均粒径が $\phi 0.05 \mathrm{~mm}$ では 0.67 $\mu \mathrm{m}$, 平均粒径が $\phi 0.3 \mathrm{~mm}$ では $1.08 \mu \mathrm{m}$, 平均粒径が $\phi 0.6 \mathrm{~mm}$ では $1.16 \mu \mathrm{m}$ から $1.44 \mu \mathrm{m}$ となっているが, 今回の結果は, 従来の傾向と一致する.

\section{2 硬さ分布におよぼすショットピーニ ングの影響}

Fig.6にSP処理後の硬さ分布を，また，Fig.7には表 層から $0.2 \mathrm{~mm}$ までの硬さ分布の詳細を示す。また, 同図 中には浸炭材の硬さ分布も併記した。SP処理後の表層硬 さは, $879 \mathrm{HV}$ から $934 \mathrm{HV}$ であり, SP 処理によって, 約

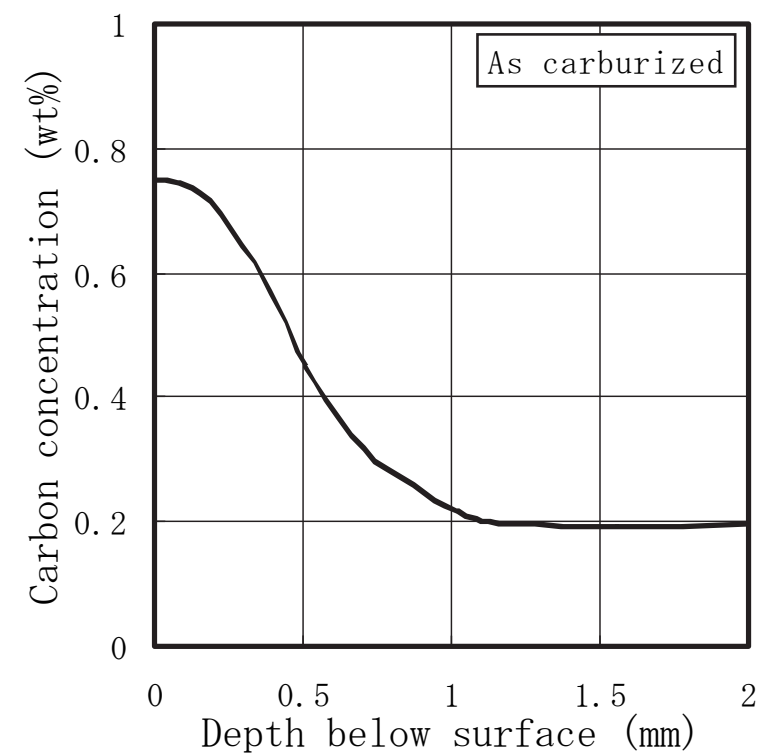

Fig.5. Carbon concentration profiles of the test specimen analyzed by EPMA.

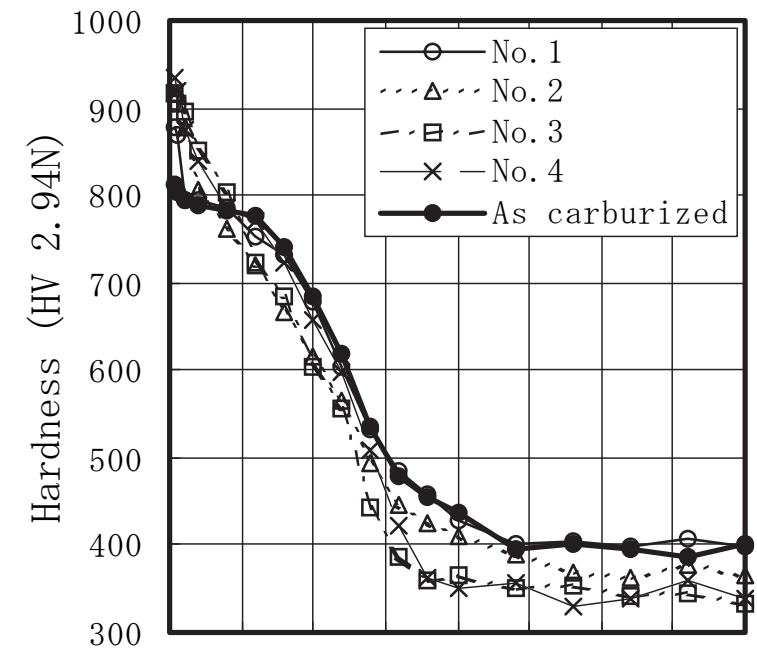

$\begin{array}{llllllllll}0 & 0.25 & 0.5 & 0.75 & 1 & 1.25 & 1.5 & 1.75 & 2\end{array}$

Distance below surface (mm)

Fig.6. Hardness profiles of the test specimen.
$70 \mathrm{HV}$ から $120 \mathrm{HV}$ 硬さが向上している. また, SP 処理 によって硬化される領域（硬化深さ）は，投射材の平均 粒径が大きくなるほど深くなり, 平均粒径が $\phi 0.05 \mathrm{~mm}$ では約 $0.05 \mathrm{~mm}$, 平均粒径が $\phi 0.3 \mathrm{~mm}$ では約 $0.1 \mathrm{~mm}$, 平均粒径が $\phi 0.6 \mathrm{~mm}$ では約 $0.2 \mathrm{~mm}$ となっているが, 今 回の結果は, 従来の傾向と一致する.

\section{3. $3 \sigma_{\mathrm{R}}$ 分布におよぼすショットピーニ ングの影響}

Fig.8にSP処理後の圧縮 $\sigma \mathrm{R}$ 分布を示す。また，同 図中には浸炭材の圧縮 $\sigma \mathrm{R}$ 分布も併記した。従来のいわ ゆる $\mathrm{HP}$ 処理後の $\sigma_{\mathrm{R}}$ の絶対值 $\left(\left|\sigma_{\mathrm{R}}\right|\right)$ は約 $1500 \mathrm{MPa}$

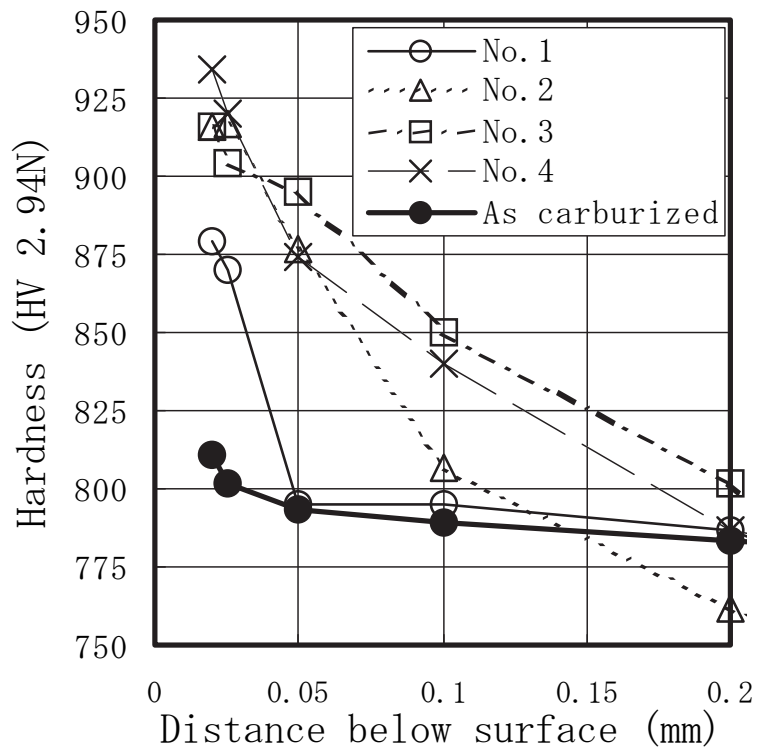

Fig.7. Detailed hardness profiles of the specimen near surface.

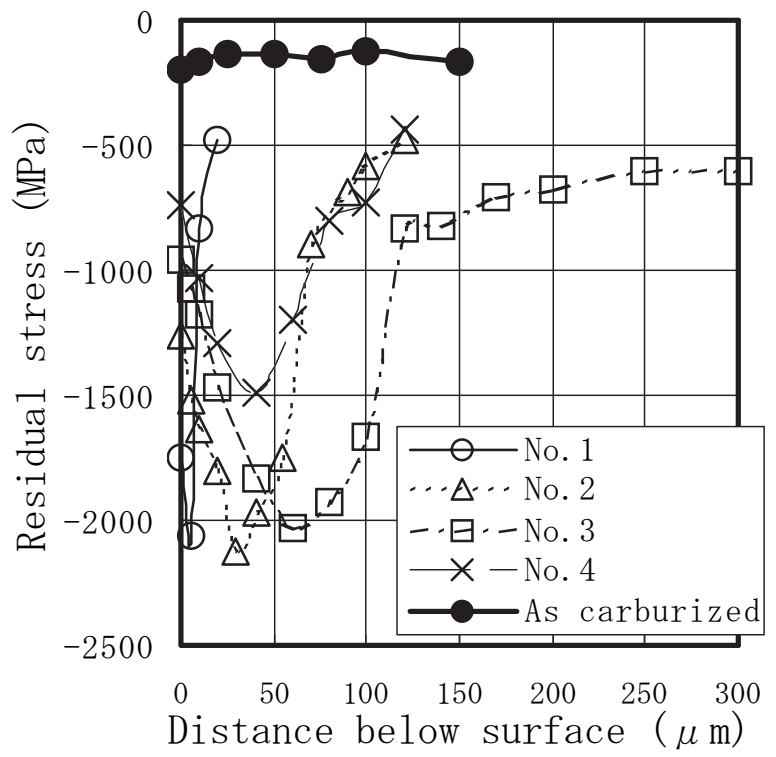

Fig.8. Residual stress profiles of the test specimen. 
となっているが，本研究で適用した $\mathrm{SP}$ 処理後の $\left|\sigma_{\mathrm{R}}\right|$ は 3 条件共に約 $2000 \mathrm{MPa}$ であり，投射材の平均粒径によっ て最大圧縮 $\sigma_{\mathrm{R}}$ の発生位置が $5 \mu \mathrm{m}$ から $60 \mu \mathrm{m}$ の範囲内 で異なり，投射材の平均粒径が大きい方が，最大圧縮 $\sigma_{\mathrm{R}}$ の発生位置が深くなることが確認できる.

過去に SP 処理による $\sigma_{\mathrm{R}}$ 分布のシミュレーションとし て, SP 条件が $\left|\sigma_{\mathrm{R}}\right|$ や最大圧縮 $\sigma_{\mathrm{R}}$ の発生位置を理論的 に予測した報告 4) 6) があるが，いずれの報告において も，投射材の平均粒径が大きくなるほど最大圧縮 $\sigma \mathrm{R}_{\mathrm{R}}$ の 発生位置は深くなることが確認されており, 今回の結果 は,これらの結果と一致する。また, 小川らの報告 ${ }^{4)}$ では, 投射材の平均粒径は $\left|\sigma_{\mathrm{R}}\right|$ に対してほとんど影響を与え ないとの結果であり，この点においても，今回の結果と 一致する。

\section{4 疲労強度}

Fig.9 にSP 処理を施した試験片の曲げ疲労試験結果を 示す。また，同図中には過去の HP 処理品の曲げ疲労試 験結果も併記した。本研究で適用した SP 処理品の $10^{5}$ 回強度は, 従来の HP 処理品に対して, 約 $15 \%$ から 35 $\%$ の高い值を示しているが, 最大圧縮 $\sigma_{\mathrm{R}}$ の発生位置 により強度が異なる結果となった。過去に $\sigma \mathrm{R}$ 分布が疲 労強度へ与える影響をまとめた報告 7) 9) があるが，い ずれの報告においても，ある深さまでの $\sigma_{\mathrm{R}}$ の積分值が 大きくなるほど疲労強度は向上することが確認されてい る。岡田ら 7) は, 歯車の歯元曲げ疲労強度の $10^{5}$ 回強度 は，最表層部から $0.4 \mathrm{~mm}$ 深さまでの $\sigma_{\mathrm{R}}$ 積分值と相関が あるとしており, 本研究においても, 同様の評価を試み, Fig.10に $0.4 \mathrm{~mm}$ 深さまでの $\sigma_{\mathrm{R}}$ 積分值と $10^{5}$ 回強度の関 係を示す. No.2, No.3, No.4の SP 処理品が $\sigma_{\mathrm{R}}$ 積分值と

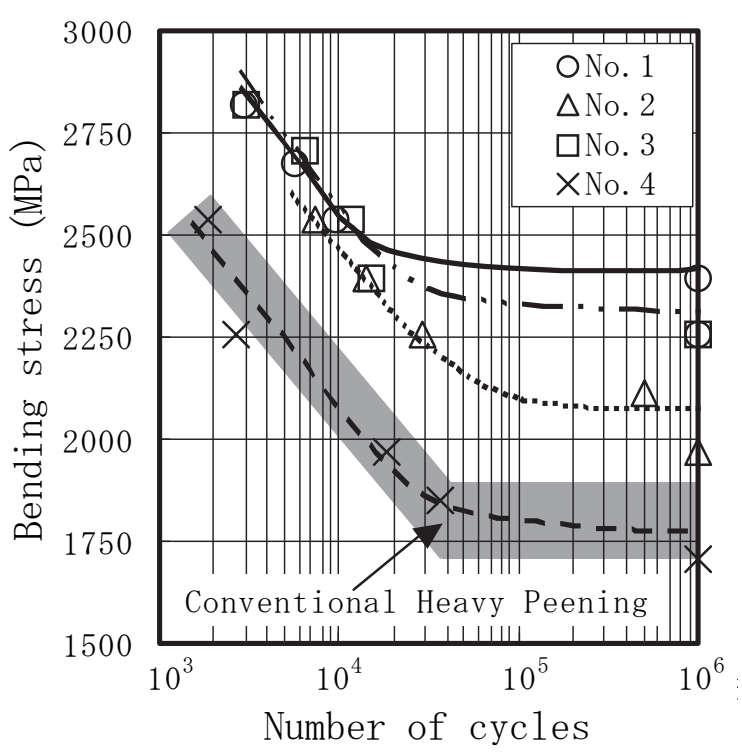

Fig.9. Bending fatigue properties.
疲労強度に明確な相関が認められるのに対して, No.1の $\mathrm{SP}$ 処理品については， $\sigma_{\mathrm{R}}$ 積分值から予想される疲労強 度に対して，明らかに高い結果となっており，予想され る疲労強度と約 $650 \mathrm{MPa}$ の差があることが確認できる.

Fig.11に各 SP 処理品の疲労寿命が $10^{4}$ 回〜 $2 \times 10^{4}$ 回 付近の疲労試験後の破面状況を示す。また，同図中には 疲労試験時の最大応力と疲労寿命も併記した. 今回の疲 労試験では, いずれの SP 条件においても疲労破壊部が 認められる。き裂発生状況およびき裂進展, 破損までの 状況を考えると, 従来の HP 条件で処理されたNo.4だけ でなく，今回，新たに適用したNo.1，No.2，No.3におい ても疲労破壊部が認められており,「初期き裂の発生 $\rightarrow き$ 裂の進展 $\rightarrow$ 破損」の経過をたどったと考えられる。また， 疲労破壊の領域は, 最大圧縮 $\sigma_{\mathrm{R}}$ の発生位置が深くなる ほど広くなっていることから， $\sigma_{\mathrm{R}}$ 層により疲労き裂の 進展が妨げられ, 疲労強度に影響を及ぼていることが 考えられる. 以上のことから, 疲労寿命と $\sigma_{\mathrm{R}}$ 分布の間 には密接な関係があると推定されたため, 破壊力学的な 考察を行い, 各サイクルでの微小き裂の伝播量を積分す ることで疲労寿命の推定を試みた.

$\mathrm{SP}$ により疲労強度が向上する原因は, 圧縮 $\sigma_{\mathrm{R}}$ の疲労 き裂伝播抑制によるものと考えられる。この残留応力の 効果は平均応力の効果として考えられるが, 太田ら 10) は, き裂進展速度 $\mathrm{da} / \mathrm{dN}$ と応力拡大係数範囲 $\Delta \mathrm{K}$ の関係の応 力比 $\mathrm{R}$ 依存性について疲労き裂伝播速度に及ぼす平均応 力の影響について調査を行い, 疲労き裂伝播寿命を予測 する実験式を提案している。 また，大路ら ${ }^{11)} は ，$ 実効負 荷に基づいてき裂開閉口挙動および有効応力拡大係数範

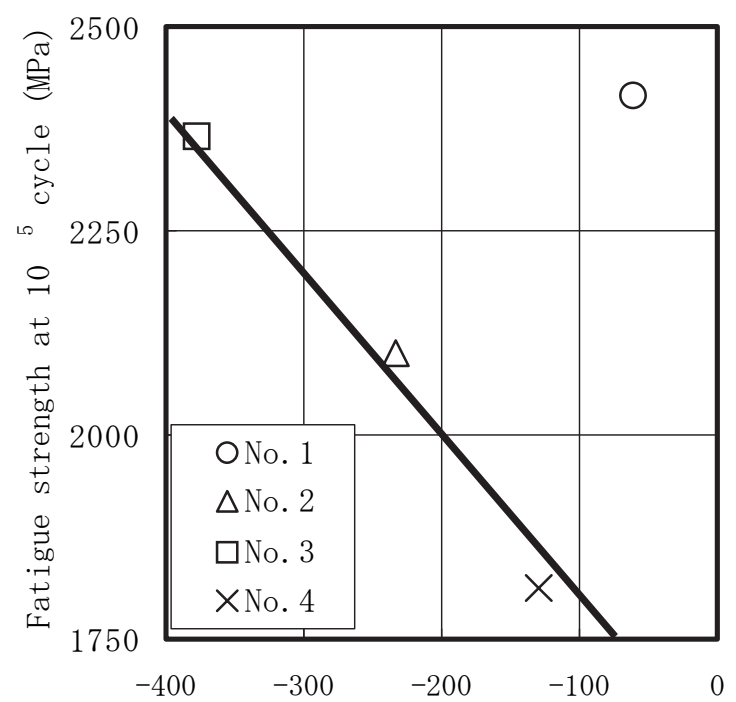

Integral value of residual stress $(\mathrm{MPa} \cdot \mathrm{mm})$

Fig.10. Relation between integral value of residual stress and fatigue strength. 
囲 $\Delta \mathrm{K}_{\mathrm{eff}}$ を推定し, き裂進展速度 $\mathrm{da} / \mathrm{dN}$ と有効応力拡大 係数範囲 $\Delta \mathrm{K}_{\mathrm{eff}}$ の関係を用いて $\sigma_{\mathrm{R}}$ 場における疲労き裂 伝播寿命を推定する方法を提案している。高硬度材での 疲労き裂伝播寿命を推定する際には，微小き裂からの疲

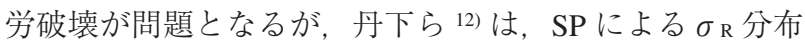
の疲労強度への影響を調査するため，微小き裂の伝播開 始条件として Hadded の整理法 ${ }^{13)}$ を用いて寿命の推定を 行っており, 本研究では, 太田らの提案する実験式を基 に丹下らの実施した方法により疲労き裂伝播寿命の推定 を行った。
Table 5 に推定に用いた諸条件を整理した。疲労き裂の 伝播寿命を推定するには, 初期き裂サイズを与える必要 があるが，粒内強度と比較すると粒界強度は相対的に弱 く, 結晶粒径が初期き裂サイズに相当すると考え, 本試 験片の平均結晶粒径である $14 \mu \mathrm{m}$ とした. Parisの式で 与えられる定数 $\mathrm{C}, \mathrm{m}$ および $\Delta \mathrm{K}_{\mathrm{th}}$ は文献值 ${ }^{14)}$ より求め た值である。 また， $\sigma_{\mathrm{R}}$ 分布は, Fig.8 に示す各 SP 処理後 の試験片のノッチ底の測定值を用いた. 以上の仮定を基 に, き裂長さが $0.4 \mathrm{~mm}$ を超えた時を疲労寿命として, 疲 労寿命の推定を行った。

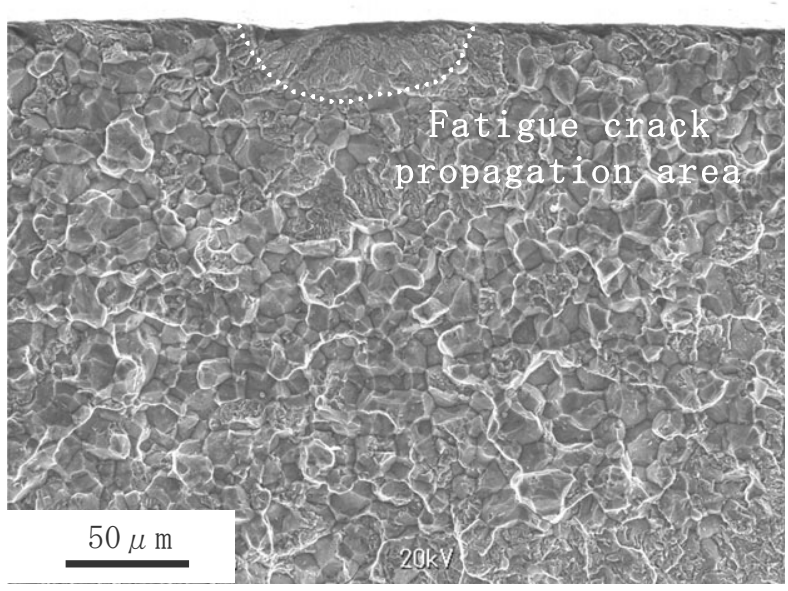

(a) No. 1 (2538 MPa, 9520 cycle)

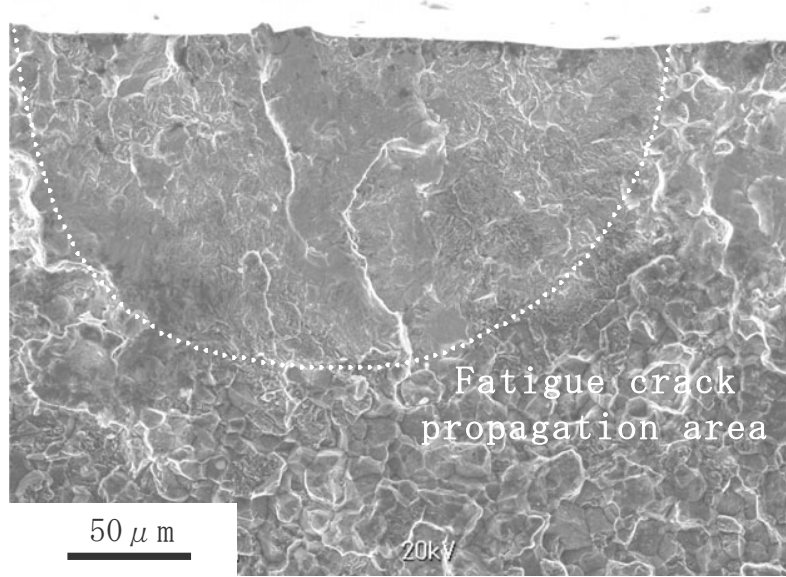

(c) No. 3 (2538 MPa, 11477 cycle)

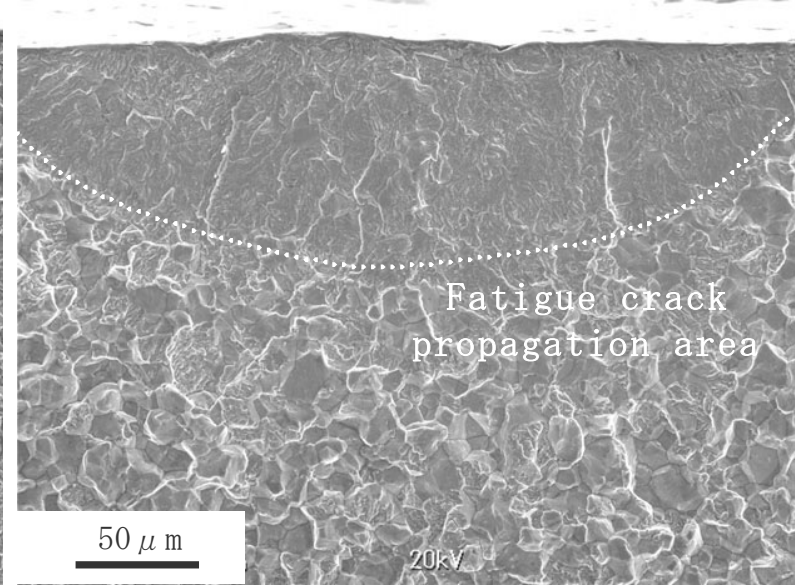

(b) No. 2(2393 MPa, 14101 cycle)

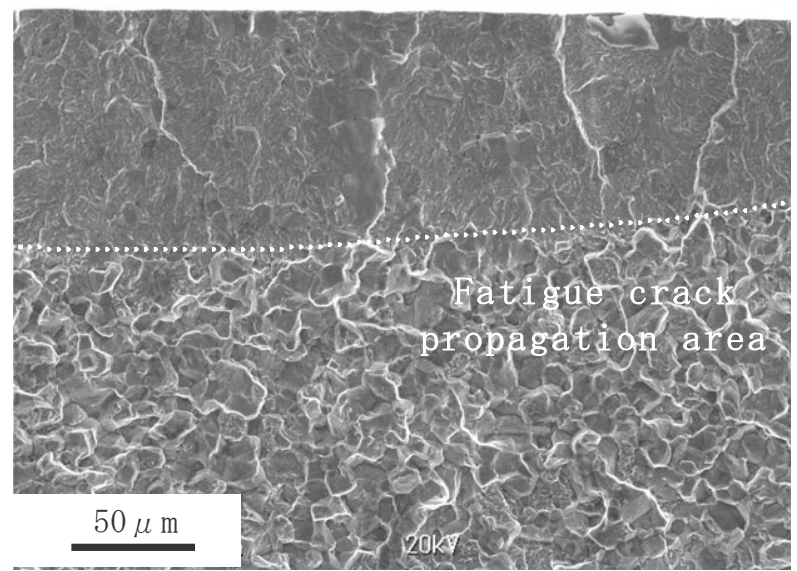

(d) No. 4(1971 MPa, 18316 cycle)

Fig.11. SEM fractograph of bending fatigue test specimen.

Table 5. Condition of calculation.

\begin{tabular}{c|c}
\hline Initial crack length $(\mu \mathrm{m})$ & 14 \\
\hline $\mathrm{C}$ & $7.04 \times 10^{-11}$ \\
\hline $\mathrm{m}$ & 2.81 \\
\hline$\Delta \mathrm{K}_{\mathrm{th}, \mathrm{R}=0}(\mathrm{MPa} \cdot \sqrt{\mathrm{m}})$ & 3.1 \\
\hline
\end{tabular}

$\mathrm{C}, \mathrm{m}: \mathrm{C}, \mathrm{m}$ of the Paris-equation $\mathrm{da} / \mathrm{dN}=\mathrm{C} \cdot \Delta \mathrm{K}^{\mathrm{m}}$

$\mathrm{R}:$ stress ratio 
Fig.12に疲労き裂の伝播寿命の推定結果を示す。ま た，同図中には疲労試験の結果も併記した。No.2, No.3, No.4 の各 SP 処理品では, 実験值と推定值が良く一致し ており, 最大圧縮 $\sigma \mathrm{R}$ の発生位置が深い方が寿命が長く なる傾向が確認でき, Fig.11に示した疲労破壊の領域の 広さと一致する。しかし, No.1では推定される寿命より も実験值が大きく上回っているが，この理由として，最 表層部に高い圧縮 $\sigma \mathrm{R}$ が付与されていることから，き裂 発生および微小き裂進展の影響が考えられる。これらの 影響を検討するため, 初期き裂サイズが $10 \mu \mathrm{m}, 5 \mu \mathrm{m}$, $1 \mu \mathrm{m}$ の場合についても, 疲労寿命の推定を行った.

Fig.13にNo.1において, 初期き裂を変化させた場合の

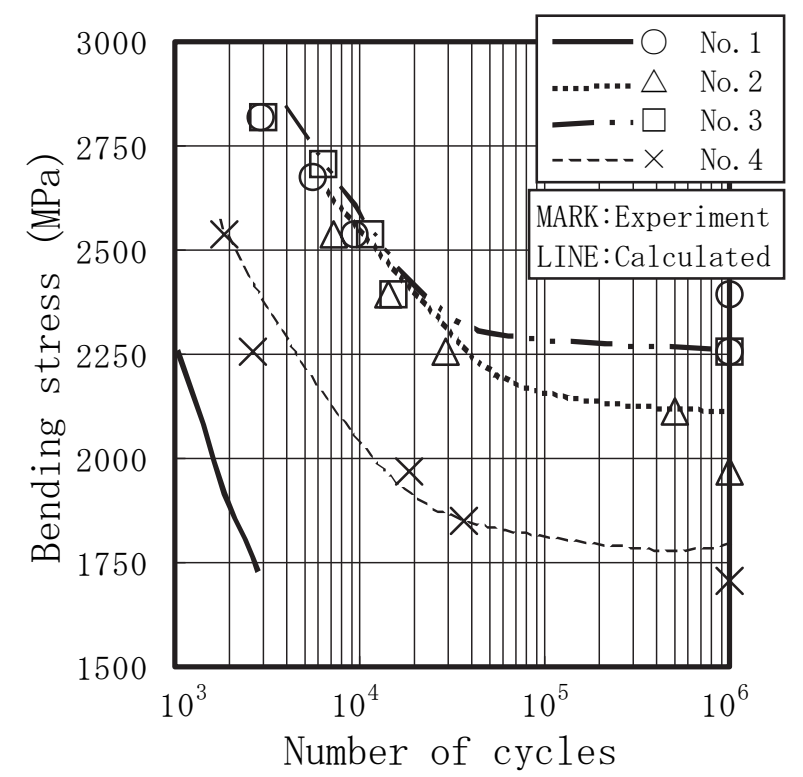

Fig.12. Calculation of bending fatigue properties.

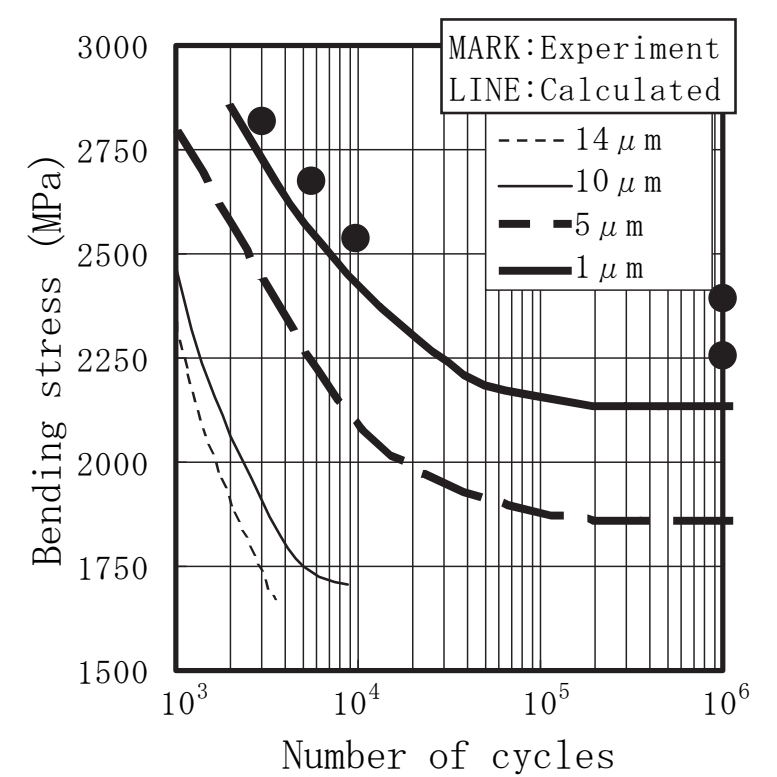

Fig.13. Influence of initial crack length on bending fatigue properties.
疲労き裂の伝播寿命の推定結果を示す。今回の疲労寿命 推定の考え方では，初期き裂を短くするほど寿命が長く なる傾向が確認でき, 推定值が実験值に近づく傾向が確 認できる.また, 江上 ${ }^{15)}$ は, 実際に微細投射材によるショッ トピーニング処理を行った試験片の各サイクルでのき裂 進展量を測定し, ノッチ底近傍に極めて高い圧縮 $\sigma_{\mathrm{R}}$ が 付与され, 最大圧縮 $\sigma_{\mathrm{R}}$ の発生位置が極表面層に存在し た場合には，発生した微小き裂の進展が著しく抑制され， 疲労強度向上効果があることを確認している．以上のこ とから, No.1での疲労強度の向上は, SP 処理により発生 した表層部のき裂の発生および微小き裂の進展が影響し ていると推察されるが, 今後, き裂発生と微小き裂進展 に着目した解析が必要と考えられる。

\section{4. 結言}

浸炭材に約 $2000 \mathrm{MPa}$ 以上の高圧縮残留応力を付与した 場合の曲げ疲労強度を調査し，以下の知見を得た。

1)2000 MPa 以上の高圧縮残留応力を付与することにより， 従来のへビーピーニング処理品以上の疲労強度の向上が 可能である.

2) 疲労き裂進展を考えると, 最大圧縮残留応力の発生位 置が表層から $60 \mu \mathrm{m}$ の範囲内では, き裂進展過程での圧 縮残留応力が高く，さらに深い方が，き裂進展の抑制効 果が高く，寿命が長くなる傾向にある.

3) 疲労強度は, ショットピーニング処理後の表層部の品 質状況によって変化し, 最表層部に高い圧縮残留応力が 付与される場合には，き裂進展だけでなく，き裂発生を 考慮する必要がある。

\section{(文 献)}

1）吉田彰, 大上祐司, 關正憲, 佐藤雅靖, 烏野勇 : 日本 機械学会論文集 $(C$ 編 $), 70$ (2004)， 2133.

2) 衛藤洋仁, 松井勝幸, 神泰行, 安藤柱: 日本機械学会 論文集（A 編），69（2003）， 733.

3）松井勝幸, 衛藤洋仁, 雪竹克也, 三阪佳孝, 安藤柱 : 日本機械学会論文集（A 編），66（2000），1878.

4）小川一義, 浅野高司: ばね論文集, 48 (2003), 31.

5）浜坂直治: 熱処理, 39 (1999), 5, 264.

6）渡邊吉弘, 長谷川典彦, 松村義和 : 材料, 44 (1995), 496, 110.

7) Y.Okada,T.Matsumoto,A.Kawaguchi,T.Tanaka,K.Nishio: Development of High Strength transmission Gears,SAE technical papers, 920761 (1992).

8) 三林雅彦, 宮田隆司, 相原秀雄 : 日本機械学会論文集 (A 編), 61 (1995), 1172. 
9）久松定興, 金沢孝, 川崎淳志: ショットピーニング技術, 9 (1992), 39.

10）太田昭彦，佐々木悦男，小管通雄 : 日本機械学会論 文集（A 編），43（1977），3149.

11）大路清嗣, 久保司郎, 辻昌宏, 小川秀樹, 桜田欣也： 日本機械学会論文集（A 編），53（1987），1516.

12）丹下彰, 高村典利, 阿久津忠良: 機械·構造物の強度 設計, 安全評価シンポジウム, 4 (1993), 56.

13) M.H.EL Hadded,T.H.Topper,K.N.Smith:Engng.Fracture mech.,11 (1979), 573.

14）金属材料疲労き裂進展抵抗デー夕集: 材料学会, (1983)

15）江上登: 精密工学会誌:72（2006），9， 1071. 